\title{
Editorial
}

\section{Art, for Children's Sake! At the Crossroads of Making, Understanding and Teaching Visual Art}

The title of the present issue of CEPS journal is taken from a commentary article by Jean Hendrickson (2014), paraphrasing the autotelic bohemian slogan "art, for art's sake«. With this paraphrase, Hendrickson takes up the discussion about the role of the arts in schools. We are used to ascribing two complementary roles to art in the educational environment. On the one hand, art is an isolated and self-sufficient subject - "art for art's sake» - in which children relax from "real work» in other subjects and make beautiful things. On the other hand, artistic skills are instrumentalised - "arts integration « - to serve other »more important «, meaning mathematical, language, natural, social, and similar subjects. Which of the two extremes should we pursue - "art for art's sake« or "arts integration « - Hendrickson asks? Most would agree that the answer is both. However, Hendrickson reminds us that such a compromise is pyrrhic and that we should completely switch our perspective to the third option - »art, for children's sake«.

According to the "art for children's sake» standpoint, art in schools should neither be treated as self-imposed »relaxation «, nor as pragmatic subordination to serve other »real« subjects, but should be recognised for the complex and fundamental role that it has in the emotional, cognitive, and social development of a child. Schools should acknowledge that the experiences that young people acquire through visual art enable them to develop fully as human beings and better understand the world in which they live. From a very early age, within their families and through contact with society, children accumulate and learn to use an increasingly greater body of visual language. Thus, the role of the school is to broaden, deepen, and structure this language progressively in many ways.

In the present issue, we conceptualise the "art for children's sake« standpoint at the intersection of making art, understanding art, and teaching art. At this crossroads, the next three topics surface as especially important to us: (1) teaching visual art, (2) teaching of visual art, and (3) teaching with visual art.

The first topic, teaching visual art, addresses the processes of learning and teaching the practice of art itself. About that, several questions arise: What is the relevance of art practice in teaching art? How does art practice influence the development of different cognitive skills in children? Should an art teacher be a practising artist himself? How can the methods of visual art practice be extended 
to art education? How should art teachers themselves be educated at universities?

The second topic, the teaching of visual art, addresses the problems regarding the role of discourse (theory) in the process of visual art education, such as: What is the role of discourse in understanding art? What types of discourses (theories) are relevant in the process of art education? What is the relationship between art practice and discourse on art (e.g., art theory, art history) in art education?

The third topic, teaching with visual art, addresses the interdisciplinary role of visual art, how teaching and learning other subjects and disciplines can be art-based, and how other fields of study can prosper from art. The relevant questions are: How can other subjects and disciplines and their competencies benefit from visual art? What are the risks and downsides (of improper use) of interdisciplinarity for the visual art itself? How can different strategies or methods of visual art (e.g., visualisations, representations, etc.) assist other areas of knowledge?

The papers presented in the focus issue address these topics in various ways and in different national and cultural contexts. They are arranged as follows.

The issue starts with a review article that makes an overview of relevant topics related to the understanding of the role of art in art education. The article, by Zlata Tomljenović and Sanja Tatalović Vorkapić, is entitled Constructivism in Visual Arts Classes and presents constructivist teaching theories and makes a conceptualisation of the possibility of their application to learning and teaching of visual arts. The main principles of constructivist-based teaching of visual arts are interpreted related to other contemporary teaching strategies and approaches, such as active learning, learning through problem-solving, and interactive approaches. By linking art education to the constructivist perspective, the paper provides a certain common thread to the issue and, in a way, underscores the articles that follow.

The issue continues with papers that focus on the theoretical conceptualisation of problems related to the relationship between art education and its parent discipline (art), to the reflection of interdisciplinarity in art education and to some dilemmas regarding artistic development.

The second article, by Petra Šobáňová and Jana Jiroutová, with the title Connecting Art Education Learning Tasks with the Artistic Field: The Factor of Quality in Art Lessons, deals with the issue of how learning tasks in art education should be related with the parent discipline - the artistic field - which quality factors should be taken into account and how the quality of art lessons could be derived based on that. The authors draw on the current theoretical and 
empirical research on quality which identifies individual quality factors.

The third article is by Bea Tomšič Amon, entitled Interdisciplinary Connections through Transmedia Narratives in Art Education. This article addresses the importance of the interdisciplinary role of art education and the education of art teachers. It presents research in which the participants, future art teachers, had to compare artistic compositions and visual compositions from nature. Understanding how art follows nature is an important goal within the education of future art teachers. Difficulty in connecting data, the transfer of knowledge, and the ability to give meaning to images, as well as understanding visual and verbal discourse, seems to be a persistent problem in many aspects within their education.

In the fourth article, with the provocative title »Do not touch it! « Today's Children's Visual Competencies in Comparison with the Pre-Digital Era in Light of their Art Educational Environment, Gabriella Pataky discusses the problem of the deterioration of visual competencies in today's children by presenting an ongoing project that sought to address two problems: first, how do plastic, spatial (3D) creative capacities develop, and how do they compare with the kindergarten's accustomed advancement of picture-creating, planar $(2 \mathrm{D})$ capabilities? Second, how do kindergartners' skills measured in the 1970s compare with those of the kindergartners of today?

The rest of the issue is dedicated to papers that focus on the empirical study of different artistic capabilities within specific groups of pupils and in different national contexts, and to papers that are practice-based and oriented to the usage of specific artistic strategies in art education.

The fifth article, entitled The State of Art Appreciation among Nine- and Ten-Year-Old Students in Slovenian Primary Schools by Jerneja Herzog and Matjaž Duh, researches how in the contemporary process of teaching fine arts, pupils' creative expression and art appreciation are used to encourage learners towards both perception and reception. The evaluation and internalisation of works of art should play an equally important role as art practice. In art education practice, they manage to provide adequate incentives for artistic expression but pay less attention to developing art appreciation.

The sixth article, written by Silvie Novotná, is entitled Artists/Ceramists in the Role of University Teachers. This study deals with the topic of tertiary education in the field of ceramics at Palacký University Olomouc, Czech Republic. The incorporation of ceramics into the education of future art teachers in Olomouc was not always a matter of course, as it is today. It underwent many changes during the second half of the $20^{\text {th }}$ century. Several personalities played significant roles in the process of the gradual consolidation of its position in 
art pedagogical education. This historical study connects its theme with sociopolitical events, as well as with the development of fine arts in the second half of the $2 \mathrm{O}^{\text {th }}$ century. Thus, it contributes to the formation of a comprehensive picture of the topic »artists as art teachers « in the Europe-wide context.

The seventh article, by Dunja Pivac and Maja Zemunik, with the title The Self-Portrait as a Means of Self-Investigation, Self-Projection and Identification among the Primary School Population in Croatia, presents self-portrait as a reflection of personality in a visual, physical sense but also in the psychological sense when self-portrait becomes a mediator of communication with oneself, a medium of self-investigation. Expressive and projective dimensions of children's drawings, which can indicate the possibility of diagnostic and potentially therapeutic activity within the regular elementary education system, were considered as a starting point. The project also tended to examine the impact of the rational-cognitive principles of teaching on children's creativity and expression. In this manner, self-portrait exists as the means of self-reflection, self-awareness and accepting the Self.

The eighth paper, entitled Cross-Curricular Analysis of Picture Books in the Fifth Grade of Primary School: A Case Study, is by Janja Batič and Petra Lebar Kac. The objective of the case study was to explore how a cross-curricular approach to planning and executing Slovenian language lessons and visual art lessons can help pupils learn about the characteristics of the picture book as a multi-modal text. The authors conducted a set of didactic activities entitled Getting to know the picture book, introducing selected picture books to pupils as part of their Slovenian language classes, which resulted in the pupils developing their receptive skills while observing and defining the structure of the texts. In visual art classes, the pupils learned about the visual features of the picture book.

The focus issue is completed with the article Teachers' Views on the Use of Photography in Teaching Arts in Croatian Primary Schools by Nina Licul. Although photography is part of a daily visual communication and gallery exhibitions, there is no structured approach to photography as a medium for learning the arts in Croatian primary schools. The objectives of the quantitative study were to determine art teachers' views on their knowledge about photography, their abilities in using photography in art teaching, obstacles in using photography in art teaching and the importance of photography in students' visual culture.

The focus issue is complemented with two articles from the Varia section and two book reviews.

The first VARIA article is written by Ceyhun Alemdağ and is entitled Changes in Learning Style Preferences of Physical Education Students. This study 
reports a three-year process to explain the change in the learning styles of physical education students. It also involves an assessment of the overall academic achievement of physical education students based on their learning style preferences throughout this process.

The second VARIA article is written by Andreja Bubić and is entitled The Relevance of Learning Approaches and Temporal Perspective for Test-Taking. The study addressed the way college students reflect on the process of preparing for tests. Specifically, it investigated the relevance of students' achievement goals, perceived academic control, and consideration of future consequences for several aspects of the test-taking process. The results obtained revealed mastery goals, perceived academic control, and the ability to disengage from the present moment as significant predictors of students' satisfaction with knowledge. Furthermore, higher success optimism was associated with having higher perceived academic control, more pronounced mastery goals, less pronounced social solidarity goals, and a higher tendency to focus on the future, whereas perceived academic control was revealed to be a significant predictor of the perceived ease of preparing for tests.

The books reviewed are related to art theory and art education. Jurij Selan reviews a book published by Boštjan Jurečič entitled A Study of the Parallels between Visual Art and Music: The Big Misconception, and Matija Purkat reviews a book published by Robert Potočnik and Iztok Devetak entitled Heritage Preservation and Interdisciplinary Approach through Fine Art and Science Education.

The focus issue is well rounded, giving different perspectives on the role of art in art education. We believe that the nine articles in the focus issue give an important insight into some of the research topics related to the "art for children's sake« standpoint.

Jurij Selan And Robert Potočnik

\section{References}

Hendrickson, J. (December 2, 2014). Art, for Children's Sake. Education Week, 34(13), 25. https:// 